\title{
T1G3/T1HG, the Dilemma
}

\author{
Diaa A Hameed* and Ahmed M Moeen \\ Urology and Nephrology University Hospital, Assiut, Egypt \\ Submission: February 14, 2017; Published: February 20, 2017 \\ *Corresponding author: Diaa A Hameed, Urology and Nephrology University Hospital, Assiut, Egypt, Email: Diaa_hameed@hotmail.com
}

\section{Editorial}

"If one uses a grading scale of 0 to 10 for difficulty in decision making (10 being the most difficult), the patient with T1G3 tumor rates a 10 " Manoharan et al. [1].

There is no better way to describe the situation of decision making in patients with stage 1 , grade 3 / high grade urothelial carcinoma (T1G3/T1HG) than this. Some of these patients get well and never recur after TURBT and intra-vesical BCG treatment, while others progress to a very aggressive muscle invasive tumor that makes cystectomy a rather late option [2]. Failing to distinguish these 2 groups of patients results in several over treatments in some and missing the opportunity of cure in others.

Several rigorous attempts were made to prognosticate T1G3/ T1HG tumors. Unfortunately, all are yet short of being optimum. Although the number of these patients is not small, the numbers involved in several recurrence and progression calculator models are not satisfactory, some important prognostic factors are ignored, and the method of treatment isn't according to the guidelines.

The EORTC bladder calculator [3] was developed and advised in the EAU guidelines. It was based on 7 trials that included 2596 patients with Ta or T1 tumors. Intra-vesical therapy was given to78\% of them, 2nd TURBT wasn't performed and BCG maintenance wasn't utilized. Six prognostic factors were used in the model: tumor number, size, recurrence rate, T category, associated CIS and grade.

For BCG treated patients, the Spanish Urological Oncology Group used the data of 4 trials including 1,062 patients who had 12 instillations over 5-6 months to formulate their recurrence/ progression risk calculator [3]. No immediate post-operative instillation or 2nd TURBT was done. Seven prognostic factors were utilized: Sex, age, prior recurrence status, number, $\mathrm{T}$ category, associated CIS and grade.

In one of the papers that is seen as containing the best available information about prognosis in patients treated with
BCG maintenance [4], the authors tried to deal with one of the most important shortcomings of the EORTC calculator, they included 1812 patient from 2 EORTC trials, however only 36\% of them were T1, and only $23 \%$ had G3 tumors. They found that T1G3 progression probability is $11.4 \%$ at 1 year and $19.8 \%$ at 5 years and their probability of death due to bladder cancer is $4.8 \%$ at 1 year and $11.3 \%$ at 5 years. However, the authors stated that "We cannot reliably identify the important subgroup of patients who do progress and die of their disease" and that better markers of immune response and molecular profiling to optimize patient selection and treatment strategy are needed. So, what are we not paying attention to? Well, to name a few:

- $\quad$ T1 sub-staging is ignored because of several factors including quality of the biopsy taken (bipolar vs monopolar?) and inexperience of many pathologists with the sub-staging.

- $\quad$ Focal vs extensive involvement of the sub-mucosa is also ignored although it seems logical that it makes a significant difference.

- $\quad$ Lympho-vascular invasion should be logically making a difference, yet is usually missing on a pathology report.

- Molecular subtypes of the tumor; urobasal A, urobasal B, squamous cancer cell like, and genomically unstable tumors are not yet included in any analysis, although we now know that this molecular taxonomy has potentisal clinical effect [5].

\section{Conclusion}

In conclusion, risk stratification of T1G3/T1HG is still an area of needed research. A well-funded, large randomized trial that involves as many prognostic factors and strictly follows the treatment guidelines is the hope for elucidating this dilemma.

\section{References}

1. Murugesan Manoharan, Mark S Soloway (2005) Optimal Management of the T1G3 Bladder Cancer. UrolClin N Am 32(2): 133-145.

2. Herr HW (1997) Tumour progression and survival in patients with T1G3 bladder tumours: 15-year outcome. Br J Urol 80(5): 762-765. 
3. European Organization for Research and Treatment of Cancer (2006) EORTC Risk Tables for Predicting Recurrence and Progression in Individual Patients with Stage Ta \& T1 Bladder Cancer. European Urology 49: 466-477.

4. Cambier S, Sylvester RJ, Collette L, Gontero P, Brausi MA, et al. (2016) EORTC Nomograms and Risk Groups for Predicting Recurrence, Progression, and Disease-specific and Overall Survival in Non-Muscle-

(C) This work is licensed under Creative BY Commons Attribution 4.0 License invasive Stage Ta-T1 Urothelial Bladder Cancer Patients Treated with 1-3 Years of Maintenance Bacillus Calmette-Guerin. Eur Urol 2016 69(1): 60-69.

5. Eriksson P, Aine M, Veerla S, Liedberg F, Sjödahl G, et al. (2015) Molecular sub types of urothelial carcinoma are defined by specific gene regulatory systems. BMC Medical Genomics 8: 25.

\section{Your next submission with Juniper Publishers will reach you the below assets}

- Quality Editorial service

- Swift Peer Review

- Reprints availability

- E-prints Service

- Manuscript Podcast for convenient understanding

- Global attainment for your research

- Manuscript accessibility in different formats

( Pdf, E-pub, Full Text, Audio)

- Unceasing customer service

Track the below URL for one-step submission https://juniperpublishers.com/online-submission.php 